\title{
A study to evaluate the antidiabetic effect of Syzygium cumini Linn. seed extract in high fructose diet induced diabetes in Albino Rats
}

\author{
Sandeep Vihan', D. B. S. Brashier ${ }^{2 *}$
}

\begin{abstract}
${ }^{1}$ Department of Pharmacology, Military Hospital, Mizoram 796310, India

${ }^{2}$ Department of Pharmacology, Armed Forces Medical College, Pune 411040, Maharashtra, India

Received: 16 March 2017

Accepted: 22 April 2017

*Correspondence to:

Dr. D. B. S. Brashier,

Email: drdickbrashier@ gmail.com

Copyright: (C) the author(s), publisher and licensee Medip Academy. This is an openaccess article distributed under the terms of the Creative Commons Attribution NonCommercial License, which permits unrestricted noncommercial use, distribution, and reproduction in any medium, provided the original work is properly cited.
\end{abstract}

\begin{abstract}
Background: The objective of the study was to evaluate the antidiabetic effect of syzygium cumini linn. Seed extract in high fructose diet induced diabetes in albino rats.

Methods: This study was conducted in two phases. In Phase I acute and chronic effects of three doses of Syzygium cumini Linn $200 \mathrm{mg} / \mathrm{kg}, 400 \mathrm{mg} / \mathrm{kg}$ and $800 \mathrm{mg} / \mathrm{kg}$ was seen in euglycaemic rats. In Phase II, the above doses of Syzygium cumini Linn were seen in diabetes induced by high fructose diet was evaluated. 5 groups of 06 animals each. Group I was given normal saline orally. Group II, III and IV were given oral Syzygium extract in the dose of 200mg/kg, $400 \mathrm{mg} / \mathrm{kg}$ and $800 \mathrm{mg} / \mathrm{Kg}$ respectively. Group V was given glibenclamide suspension $10 \mathrm{mg} / \mathrm{Kg}$ orally. Blood glucose was measured before starting this phase (Day 0), at the end of fructose feeding (day 28) and weekly thereafter up to the end of the treatment period (i.e. on days $35,42,49,56$ ).

Results: In phase I of the study, Syzygium extract had no effect on the mean blood glucose levels when given in the doses of 200,400 and $800 \mathrm{mg} / \mathrm{kg}$, from 1-24 hours. After chronic administration to euglycemic rats for 4 weeks, Syzygium extract also did not produce any significant change in blood glucose levels when given at various doses from $200-800 \mathrm{mg} / \mathrm{kg}$. Treatment with all the three doses of Syzygium cumini extract $(200,400$ and $800 \mathrm{mg} / \mathrm{kg})$ produced a significant reduction in the blood glucose level. ( $\mathrm{P}$ value $<0.001$ as compared to group I). The glucose lowering effect started at the end of 1 weeks and it increased till the end of the study in all the groups.

Conclusions: Syzygium cumini Linn extract has no effect on the blood glucose levels of euglycemic animals. Syzygium cumini Linn extract can reduce blood glucose levels in high fructose diet induced diabetic rats, in a dose dependent and time dependent manner.
\end{abstract}

Keywords: Aqueous extract, Antidiabetic activity, Albino rats, Syzygium cumini

\section{INTRODUCTION}

Diabetes mellitus is significantly affecting population of both developed and developing nations. ${ }^{1}$ It can be classified into two broad categories, Type 1, Insulin dependent Diabetes mellitus(IDDM) and Type 2 NonInsulin Dependent Diabetes mellitus (NIDDM). ${ }^{2}$ Out of these two types, type 2 DM accounts for $90 \%$ of all diabetes cases. ${ }^{3}$ Type 2 DM is manifested by relative deficiency in insulin, caused by insulin resistance (IR) and lack of target tissue responsiveness towards insulin. Insulin resistance is major cause in majority of cases., ${ }^{4,5}$ Despite of tremendous research in finding treatment of diabetes mellitus and number of new drugs being approved each year, still a long way to go as no drug is being found to have a definite treatment. ${ }^{6}$ IR can only partially be reversed by parenteral insulin, which is a cumbersome job for patients to be performed on daily basis. Due to above problems search for an ideal treatment continues. ${ }^{7}$

Syzygium cumini Linn. (Syn. Eugenia jambolana Linn.) or Jamun tree is commonly found in India, and have shown many medicinal effects like antidiabetic, antihypertensive, carminative, astringent, anti-diarrhoea \& diuretic effects. ${ }^{8}$ This plant occupies a special place in traditional medicine and is a prominent component of 
many Indian household concoctions. ${ }^{9,10}$ Therefore, this study was undertaken to evaluate antidiabetic effects of Syzygium cumini Linn. in euglycemic, and high fructose induced diabetes.

\section{METHODS}

\section{Animal collection}

Healthy young adult Wistar albino rats of either sex, weighing between 150-250 g, were used as experimental animals in this study. They were housed in clean cages and were maintained on standard laboratory diet and water ad-libitum. After a five-day acclimatization period, the rats were used for the study.

\section{Preparation of Syzygium cumini Linn. extract}

Seeds of Syzygiumcumini were dried and crushed using a grinder. Aqueous extract was prepared using Soxhalet apparatus. Extract was further dried by putting it in flat petri dishes till it was reduced to a crust at the bottom of the petri dish. This brownish- black crust was used for the study.

\section{Antidiabetic activity}

\section{Phase I}

Phase I of the study was conducted to evaluate the acute and chronic effects of extract on blood glucose levels in euglycemic animals. Total 36 animals were divided into 3 sets (A, B and C) of 12 animals each. Each set was further sub-divided into test and control groups having 6 animals each. Blood glucose levels were measured at 1 and 4 hours in set A, 2 and 6 hours in set B and 16 and 24 hours in set $\mathrm{C}$ after Syzygium extract administration.

All of these three sets of animals were given three doses of Syzygium extract i.e. $200 \mathrm{mg} / \mathrm{kg}, 400 \mathrm{mg} / \mathrm{kg}$ and 800 $\mathrm{mg} / \mathrm{kg}$ at gap of 30 day. To evaluate the chronic effects of extract, 18 euglycemic rats were divided into 3 groups of 6 animals each. They were then treated for next 4 weeks as follows: Group I, II and II were given Syzygium extract in the dose of $200 \mathrm{mg} / \mathrm{kg}, 400 \mathrm{mg} / \mathrm{kg}$, and $800 \mathrm{mg} / \mathrm{kg}$ respectively. Blood glucose levels were checked every week.

\section{Phase II}

In this phase of the study, 42 rats were given high fructose diet for 04 weeks. At the end of 04 weeks, their blood glucose levels were measured and the rats having blood glucose levels more than $140 \mathrm{mg} / \mathrm{dl}$ were selected. 30 such animals were randomly divided into 5 groups of 06 animals each. Group I was given normal saline orally. Group II, III and IV were given oral Syzygium extract in the dose of $200 \mathrm{mg} / \mathrm{kg}, 400 \mathrm{mg} / \mathrm{kg}$ and $800 \mathrm{mg} / \mathrm{Kg}$ respectively. Group V was given glibenclamide suspension $10 \mathrm{mg} / \mathrm{Kg}$ orally. Blood glucose was measured before starting this phase (Day 0), at the end of fructose feeding (day 28) and weekly thereafter up to the end of the treatment period (i.e. on days $35,42,49,56$ ). Blood was collected from the orbital plexus under ketamine anesthesia (40 mg/kg i.v.). Blood glucose and other parameters were estimated by standardized biochemical methods.

\section{Statistical analysis}

Hypoglycemic effects of the extract on euglycemic animals were analyzed by two tailed, unpaired student's $t$ test. $\mathrm{P}<0.05$ was considered to be statistically significant. Effects of the extract in high fructose induced diabetic rats were analyzed by one way ANOVA and followed by post hoc Tukey's test. $\mathrm{P}<0.05$ was considered to be statistically significant.

\section{RESULTS}

\section{Phase I}

Effects of Syzygium cuminiLinn. extract on blood glucose of euglycemic animals

In phase I of the study, Syzygium extract had no effect on the mean blood glucose levels when given in the doses of 200, 400 and $800 \mathrm{mg} / \mathrm{kg}$, from 1-24 hours (Table 1). It shows that Syzygium extract per se does not possess any hypoglycemic activity in normal animals at all doses. After chronic administration to euglycemic rats for 4 weeks, Syzygium extract also did not produce any significant change in blood glucose levels when given at various doses from $200-800 \mathrm{mg} / \mathrm{kg}$ (Table 2).

\section{Phase II}

Effects of Syzygium cumini Linn. extract on blood glucose of fructose-induced diabetic rats

Treatment with all the three doses of Syzygium cumini extract $(200,400$ and $800 \mathrm{mg} / \mathrm{kg})$ produced a significant reduction in the blood glucose level. ( $\mathrm{P}$ value <.001 as compared to group I). The glucose lowering effect started at the end of 1 weeks and it increased till the end of the study in all the groups (Table 3 ). These results show that the reduction in blood glucose levels produced by Syzygium cumini extract progresses in a dose dependent manner. Effect was clearly evident after 1 week of treatment and increased with time. The fall in blood glucose level produced by Syzygium cumini extract showed maximal effect in the dose of $800 \mathrm{mg} / \mathrm{Kg}$ in a dose dependent manner. The results are comparable to the standard drug, glibenclamide. Blood glucose levels did not fall to normal in any of the groups. 
Table 1: Acute effects of Syzygium cumini Linn. extract on changes in blood glucose levels (mg/100ml) in Euglycemic Rats.

\begin{tabular}{|c|c|c|c|c|c|c|}
\hline & After $1 \mathrm{hr}$ & After 2 hrs & After 4 hrs & After 6 hrs & After 16 hrs & After $24 \mathrm{hrs}$ \\
\hline Control (Normal saline) & $1.67 \pm 0.77$ & $1.16 \pm 0.54$ & $1.83 \pm 1.08$ & $1.33 \pm 0.73$ & $1.33 \pm 0.63$ & $0.66 \pm 0.44$ \\
\hline $\begin{array}{l}\text { Syzygium extract ( } 200 \\
\mathrm{mg} / \mathrm{kg})\end{array}$ & $0.5 \pm 0.31$ & $1.16 \pm 0.60$ & $1.16 \pm 0.60$ & $3 \pm 1.41$ & $0.66 \pm 0.44$ & $2.166 \pm 1.044$ \\
\hline $\begin{array}{l}\text { Syzygium extract } \\
(400 \mathrm{mg} / \mathrm{kg})\end{array}$ & $2.83 \pm 2.25$ & $1.33 \pm 0.63$ & $3.5 \pm 2.67$ & $2.5 \pm 1.19$ & $1.0 \pm 0.51$ & $3 \pm 1.39$ \\
\hline $\begin{array}{l}\text { Syzygium extract } \\
(800 \mathrm{mg} / \mathrm{kg})\end{array}$ & $0.5 \pm 0.31$ & $1.33 \pm 0.63$ & $1.16 \pm 0.60$ & $2.5 \pm 1.19$ & $0.66 \pm 0.44$ & $2.166 \pm 1.044$ \\
\hline
\end{tabular}

All values show mean change from $0 \mathrm{hr}$ in blood glucose levels.

$\mathrm{N}=6$ in each group, ${ }^{*}=\mathrm{p}<0.05, * *=\mathrm{p}<0.01, * * *=\mathrm{p}<0.001$ as compared to control group of the same dose range by Student's $\mathrm{t}$ test

Table 2: Chronic effects of Syzygium cumini Linn. extract on blood glucose levels ( $\mathrm{mg} / 100 \mathrm{ml})$ of euglycemic rats.

\begin{tabular}{|llllll|}
\hline & 0 Day & $\mathbf{7}^{\text {th }}$ Day & $\mathbf{1 4}^{\text {th }}$ Day & $\mathbf{2 1}^{\text {st }}$ Day & $\mathbf{2 8}^{\text {th }}$ Day \\
\hline Syzygium extract $(200 \mathrm{mg} / \mathrm{kg})$ & $89 \pm 1.52$ & $87.83 \pm 1.40$ & $86.66 \pm 1.33$ & $85.33 \pm 1.45$ & $84.5 \pm 1.17$ \\
\hline Syzygium extract $(400 \mathrm{mg} / \mathrm{kg}$ & $86.16 \pm 3.27$ & $85.6 \pm 3.43$ & $85 \pm 3.49$ & $84.33 \pm 3.39$ & $83.16 \pm 3.22$ \\
\hline Syzygium extract $(800 \mathrm{mg} / \mathrm{kg})$ & $79.16 \pm 1.93$ & $78.5 \pm 1.72$ & $77 \pm 1.78$ & $76.33 \pm 2.02$ & $75.16 \pm 1.90$ \\
\hline
\end{tabular}

$\mathrm{N}=6$ in each group, ${ }^{*}=\mathrm{p}<0.05,{ }^{* *}=\mathrm{p}<0.01,{ }^{* * *}=\mathrm{p}<0.001$ as compared to the baseline values (on day 0 ) in the same group by paired $\mathrm{t}$ test

Table 3: Effect of chronic administration of Syzygium cumini extract on blood glucose (mg/100 ml) of high fructose diet induced diabetic rats.

\begin{tabular}{|c|c|c|c|c|c|c|}
\hline Treatment & 0 Day & $28^{\text {th }}$ Day & $\begin{array}{l}3^{\text {th }} \text { Day ( } 1 \\
\text { week of } \\
\text { treatment) }\end{array}$ & $\begin{array}{l}42^{\text {nd }} \text { Day } \\
(2 \text { weeks of } \\
\text { treatment })\end{array}$ & $\begin{array}{l}49^{\text {th }} \text { Day } \\
\text { ( } 3 \text { weeks of } \\
\text { treatment) }\end{array}$ & $\begin{array}{l}56^{\text {th }} \text { Day } \\
\text { (4 weeks of } \\
\text { treatment) }\end{array}$ \\
\hline Group I (Control) & $88.33 \pm 0.61$ & $157.83 \pm 0.83$ & $163 \pm 1.12$ & $161.33 \pm 0.98$ & $162.66 \pm 0.66$ & $165.66 \pm 1.96$ \\
\hline $\begin{array}{l}\text { Group II } \\
\text { (S. cumini } 200 \\
\mathrm{mg} / \mathrm{kg} \text { ) }\end{array}$ & $88 \pm 0.73$ & $156.5 \pm 1.14$ & $149.66 \pm 1.20^{* * *}$ & $134.66 \pm 0.66^{* * *}$ & $126.66 \pm 0.42^{* * *}$ & $114.33 \pm 0.95^{* * *}$ \\
\hline $\begin{array}{l}\text { Group III } \\
\text { (S. cumini } 400 \\
\mathrm{mg} / \mathrm{kg} \text { ) }\end{array}$ & $86.66 \pm 1.11$ & $160 \pm 0.73$ & $153.66 \pm 0.95^{* * *}$ & $141.33 \pm 0.42^{* * *}$ & $124.66 \pm 1.11^{* * *}$ & $107.66 \pm 0.61^{* * * *}$ \\
\hline $\begin{array}{l}\text { Group IV } \\
\text { (S. cumini } 800 \\
\mathrm{mg} / \mathrm{kg} \text { ) }\end{array}$ & $88.33 \pm 0.95$ & $158.66 \pm 0.98$ & $143.66 \pm 1.30^{* * *}$ & $134.33 \pm 1.20^{* * *}$ & $122.33 \pm 1.30^{* * *}$ & $103.33 \pm 0.42^{* * *}$ \\
\hline $\begin{array}{l}\text { Group V } \\
\text { (Glibenclamide } \\
10 \mathrm{mg} / \mathrm{kg} \text { ) }\end{array}$ & $90 \pm 1.15$ & $157 \pm 1.12$ & $152 \pm 0.73^{* * *}$ & $125.33 \pm 0.66^{* * *}$ & $117 \pm 0.44^{* * *}$ & $103 \pm 0.44^{* * *}$ \\
\hline
\end{tabular}

$\mathrm{N}=6$ in each group, ${ }^{*}=\mathrm{p}<0.05,{ }^{* *}=\mathrm{p}<0.01,{ }^{* * *}=\mathrm{p}<0.001$. As compared to group I at similar days

\section{DISCUSSION}

Diabetes mellitus is a chronic disorder having considerable effects on morbidity and mortality worldwide. ${ }^{11}$ Various plant extract have been shown to have anti diabetic effects. Syzygium cumini Linn or Jamun tree is one of such plant. ${ }^{12}$ Its extract has shown to be having antidiabetic properties. Syzygium cumini Linn. extract did not produce any significant alteration in blood glucose levels of euglycemic rats after either acute or chronic administration for 4 weeks. During this period, all the doses $(200 \mathrm{mg} / \mathrm{kg}, 400 \mathrm{mg} / \mathrm{kg}, 800 \mathrm{mg} / \mathrm{kg})$. In high fructose diet induced hyperglycemic rats, Syzygium cumini Linn extract lead to reduction in fasting blood glucose levels starting at the end of 1 week and the effect increased till the end of the study in all groups. The effect was dose dependent and improved with time. The results are comparable to glibenclamide, a standard oral hypoglycemic agent. Blood glucose levels did not fall to normal in any of the groups.

Our result indicates that the seed extract does not affect the normal physiological functions governing glucose metabolism so no effect on glucose level in healthy 
animals but due to some mechanisms not known clearly, is able to correct the glucose metabolic defects due to high dose of fructose feeding. These results point towards a combination of mechanisms including insulin secretagogues/mimetic action as well as increasing the sensitivity of insulin. However, the lack of acute hypoglycemic effects cannot be explained and probably point towards a lack of any secretagogues or acute effect. This study also clearly brings out the effect of Syzygium cumini Linn. extract on various biochemical parameters like liver and kidney function tests indicating safety of the extract. While there is a fair amount of evidence outlining the efficacy of Syzygium cumini Linn extract in animal models of diabetes, it's mechanism of action and isolation of bioactives is required to be elucidated by further research work.

\section{CONCLUSION}

Syzygiumcumini Linn extract has no effect on the blood glucose levels of euglycemic animals. Syzygium cumini Linn extract can reduce blood glucose levels in high fructose diet induced diabetic rats, in a dose dependent and time dependent manner. This study clearly demonstrates the efficacy of Syzygium cumini Linn extract in animal models of diabetes. However, it's mechanism of action requires further investigation should be elucidated by further research.

\section{Funding: No funding sources}

Conflict of interest: None declared

Ethical approval: The study was approved by the Institutional Ethics Committee

\section{REFERENCES}

1. Gerrits EG, Landman GW, Bilo HJ. Mortality trends in diabetes mellitus. JAMA Intern Med. 2015;175(3):469.

2. Nolte MS, Karam JH. Pancreatic Hormones and Antidiabetic Drugs. In: Bertram G Katzung, editor. Basic and Clinic Pharmacology. 13 ${ }^{\text {th }}$ Ed, McGraw Hill; 2015:683-703.

3. Davis SN. Insulin, oral hypoglycemic agents, and the pharmacology of the endocrine pancreas. In: Brunton LL, Lazo JS, Parker KL, editors. Goodman and Gilman's The Pharmacological Basis of Therapeutics. 12 $2^{\text {th }}$ Ed. McGraw Hill; 2011:16131645.

4. Simental-Mendía LE, Rodríguez-Morán M, GómezDíaz R. Insulin resistance is associated with elevated transaminases and low aspartate aminotransferase/alanine aminotransferase ratio in young adults with normal weight. Eur J Gastroenterol Hepatol. 2016;23-26.

5. Zhang L, Zhang M, Wang JJ Association of TCF7L2 and GCG Gene Variants with Insulin Secretion. Insulin Resistance, and Obesity in New-onset Diabetes. Biomed Environ Sci. 2016;29(11):814-7.

6. McEwan P, Bennett $\mathrm{H}$, Qin L, Bergenheim K, Gordon J, Evans M. An alternative approach to modelling HbA1c trajectories in patients with type 2 diabetes mellitus. Diabetes Obes Metab. 2016;17-19.

7. Davis SN. Insulin, oral hypoglycemic agents, and the pharmacology of the endocrine pancreas. In: Brunton LL, Lazo JS, Parker KL, editors. Goodman and Gilman's The Pharmacological Basis of Therapeutics. $11^{\text {th }}$ Ed. McGraw Hill; 2006:16131645.

8. Yousaf S, Hussain A, Rehman S, Aslam MS, Abbas Z. Hypoglycemic and hypolipidemic effects of Lactobacillus fermentum, fruit extracts of Syzygium cumini and Momordicacharantia on diabetes induced mice. Pak J Pharm Sci. 2016;29(5):1535-40.

9. Coelho GD, Martins VS, do Amaral LV, Novaes RD, Sarandy MM, Gonçalves RV. Applicability of Isolates and Fractions of Plant Extracts in Murine Models in Type II Diabetes: A Systematic Review. Evid Based Complement Alternat Med. 2016;43-45.

10. Baldissera G, Sperotto ND, Rosa HT. Effects of crude hydroalcoholic extract of Syzygium cumini (L.) Skeels leaves and continuous aerobic training in rats with diabetes induced by a high-fat diet and low doses of streptozotocin. J Ethnopharmacol. 2016;194:1012-21.

11. Dusane MB, Joshi BN, Zhong X, Jie Y, Bao He X. Seeds of Syzygium cumini (L.) Skeels: potential for islet regeneration in experimental diabetes. Agharkar Research Institute, Pune, India. 2011 Dec;9(12):1380-7.

12. Rao SS, Najam R. Efficacy of combination herbal product (Curcuma longa and Eugenia jambolana) used for diabetes mellitus. Pak J Pharm Sci. 2016;29(1):201-4.

Cite this article as: Vihan S, Brashier DBS. A study to evaluate the antidiabetic effect of Syzygium cumini Linn. seed extract in high fructose diet induced diabetes in Albino Rats. Int $\mathbf{J}$ Basic Clin Pharmacol 2017;6:1363-6. 